\title{
Identification and partial characterization of proteolytic activity of Enterococcus faecalis relevant to their application in the dairy industry
}

\author{
Paulina Worsztynowicz ${ }^{\bowtie}$, Agnieszka Olejnik-Schmidt, Wojciech Białas \\ and Włodzimierz Grajek
}

Department of Biotechnology and Food Microbiology, Poznań University of Life Sciences, Poznań, Poland

\begin{abstract}
Bacteria of the Enterococcus genus represent a group of lactic acid bacteria (LAB). They occur ubiquitous in many traditional fermented foods, especially in artisanal cheeses, playing a beneficial role in the development of cheese flavor. Several enterococcal strains are successfully used as pharmaceutical probiotics and some of them are able to produce bacteriocin and bioactive peptides. However, some Enterococcus strains can cause nosocomial infections, including endocarditis, urinary tract infections and bacteremia. Therefore, the questions on their safe use in foods are still valid. The main goals of the study were to investigate a proteolytic potential and to identify key enzymes of the proteolytic system in Enterococcus faecalis isolated from artisan Polish cheeses. An extracellular-secreted (E) and a cell envelope proteinase (CEP) were isolated and the enzymes' activities depending on bacterial growth phase were evaluated. CEP displayed a higher protease activity than E, and a CEP fraction has been purified 70 -fold by a method that included precipitation, diafiltration and gel filtration chromatography. The molecular mass of the enzyme has been estimated by SDS-PAGE to be $\sim 25 \mathrm{kDa}$. The maximum enzyme activity of the proteinase has been observed at $\mathrm{pH}$ 6.9 and $37^{\circ} \mathrm{C}$. The enzyme was able to hydrolyze: casein, bovine serum albumin, a-lactalbumin, $\beta$-lactoglobulin, but not Leu-pNa. The results of zymography, SDS- PAGE and LC-MS-MS/MS data had allowed us to identify key enzymes of the proteolytic system of $E$. faecalis as coccolysin and glutamyl endopeptidase. To asses microbiological safety of the tested strain, evaluation of virulence factors presence and antibiotic susceptibility was also conducted.
\end{abstract}

Key words: Enterococcus faecalis, proteolytic activity, coccolysin

Received: 15 October, 2018; revised: 23 December, 2018; accepted: 08 January, 2019; available on-line: 04 February, 2019

e-mail: paulina.worsztynowicz@up.poznan.pl

Abbreviations: BCA, bicinchoninic acid; CEP, cell envelope proteinase; $\mathrm{DH}$, degree of hydrolysis; eq, equivalent; $\mathrm{E}$, extracellularsecreted protease; LAB, lactic acid bacteria; Leu-pNa, L-leucinepNa; LC-MS-MS/MS, liquid chromatography-tandem mass spectrometry; OD, optical density; PCR, polymerase chain reaction; pNa, p-nitroaniline; OPA, o-phthalaldehyde; RSM, response surface methodology; SDS-PAGE, sodium dodecyl sulfate polyacrylamide gel electrophoresis; TCA, trichloroacetic acid; WPC, whey protein concentrate

\section{INTRODUCTION}

Bacteria of the Enterococcus genus are a part of harmless commensal species of the human gastrointestinal tract and are also widespread in the dairy fermented foods. They belong to a group of lactic acid bacteria (LAB). However, the presence of E. faecalis in food has been long considered to be a result of unhygienic conditions during production. Whereas, Mundt (1986) had shown that the occurrence of $E$. faecalis in many food products is not always related to direct fecal contamination. Moreover, in the Commission Regulation (EC) No 1441/2007 of 5 December 2007 on microbiological criteria for foodstuffs, a maximum level for the presence of coliforms and Escherichia coli was set, as indicators of hygiene, but there was no limit for the enterococci and the presence of enterococci in many food products, especially in cheeses where it is often considered as beneficial. Recent studies indicated that enterococci share interesting biotechnological traits, such as bioactive peptides and bacteriocin production (Foulquie' Moreno et al., 2006; Hirota et al., 2007; Korhonen \& Pihlanto, 2006). Several strains of E. faecium (e.g., E. faecium SF68 ${ }^{\circledR}$ ) and E. faecalis (e.g., Symbioflor $1^{\circledR}$ ) are also used in microbiological therapy, aimed at restoring the balance of the composition of the host intestinal microflora and in the auxiliary treatment of diarrhea (Franz et al., 2011). Surveillance and well established scientific evidence support safety of these strains for both, human and animal applications (Allen et al., 2010).

The positive role of enterococci in the processing of some dairy products is associated with their proteolytic activity, among others (Wilkinson et al., 1994; Giraffa, 2003; Gútiez et al., 2013). Proteolytic system of LAB is composed of extracellular-secreted and surface associated proteinase, peptide transporters and various intracellular peptidases (Law \& Haandrikman, 1997; Liu et al., 2010). It plays an important role in generating necessary peptides and amino acids for bacterial growth. Moreover, the secreted and the surface enzymes of the starter or non-starter bacteria are recognized as the molecules which play a key role in the dairy industry because thanks to them the fermented products gain unique organoleptic properties (Broadbent \& Steele, 2007; González et al., 2010; Hernández-Ledesma et al., 2011). However, despite the fact that enterococci were isolated from many traditional cheeses manufactured in Spain, Greece, Italy and Poland, previous studies on $\mathrm{LAB}$ proteolytic enzymes were mainly restricted to the genera of Lactobacillus and Lactococcus (Pritchard \& Coolbear, 1993; Reid et al., 1994). There are only a few studies regarding the proteolytic system of enterococci in comparison with the other LAB species (González et al., 2010; Pessione et al., 2012). Perhaps the lack of de- 
tailed information on the proteolytic enzymes produced by non-starter LAB (including enterococci), may be the reason for the difficulties in transfer of the production of traditional cheeses to the large-scale manufacturing.

On the other hand, enterococci are often described as a biological threat. E. faecalis has been mainly implicated as the causal agents of $10 \%$ of total nosocomial infections and poses a significant treatment challenge (Kaye, 1982; Murray, 1990; Del Papa et al., 2007). Many studies on enterococcal pathogenicity have focused on investigation of virulence factors in the enterococcal genome which include: extracellular surface proteins, aggregation substance, gelatinase and extracellular superoxide and multidrug resistance (Foulquié Moreno et al., 2006; Lepage et al., 2006; Solheim et al., 2009; Gútiez, 2013). The results have shown that several of the virulence factors are detected in strains of clinical, as well as food origin (Cariolato et al., 2008; Chajęcka-Wierzchowska et al., 2017; Medeiros et al., 2014). However, a higher incidence of some of the virulence determinants was found in the clinical enterococci isolates.

The goals of this research were to investigate the proteolytic activity of E. faecalis isolated from artisan Polish cheese and to identify and characterize key enzymes of its proteolytic system. To evaluate microbiological safety of the tested strain, antibiotic susceptibility was determined and the genome was tested for the presence of selected virulence factors.

\section{MATERIALS AND METHODS}

Materials. Skim milk powder was purchased from Laktopol (Poland); whey protein concentrate (WPC-80) from Spomlek (Poland); Unstained Protein Molecular Weight Marker from Fermentas (Lithuania); amido black $10 \mathrm{~B}$ and MRS-broth from Merck Millipore (Darmstadt, Germany); Genomic Mini AX Bacteria Kit and StartWarm $2 \times$ PCR Master Mix from A\&A Biotechnology (Poland); Antimicrobial Susceptibility test discs from Oxoid; Mueller-Hinton agar from Biocorp (Poland). Azocasein, L-leucine-pNa (Leu-pNa), o-phthalaldehyde (OPA), bicinchoninic acid (BCA) kit, lysozyme and Coomassie Brilliant Blue R-250 were purchased from Sigma Aldrich (Poland).

All other chemicals used were of analytical grade and were purchased from POCH (Poland).

Microorganism and growth conditions. Enterococcus faecalis $2 / 28$ used in this study was obtained from the culture collection of the Department of Biotechnology and Food Microbiology, Poznań University of Life Sciences (Poland). This strain was recovered from artisan cheeses produced in the Podhale region (Poland). E. faecalis was cultured in the MRS broth at $37^{\circ} \mathrm{C}$ and stored frozen at $-20^{\circ} \mathrm{C}$ in the MRS broth supplemented with $20 \%$ (w/v) glycerol.

The strain was grown in reconstituted $(11 \%, \mathrm{w} / \mathrm{v})$ skim milk powder. The skim milk was first pasteurized at $90^{\circ} \mathrm{C}$ for $20 \mathrm{~min}$ and then inoculated. The inoculated milk $(2 \%, \mathrm{v} / \mathrm{v})$ was incubated at $37^{\circ} \mathrm{C}$ for $48 \mathrm{~h}$ under constant stirring.

Biosynthesis and isolation of bacterial proteases. E. faecalis cell fractions were prepared using a modified Requena and others (Requena et al., 1993) protocol. After 3-48 h of milk fermentation, conducted under conditions as cited above, $100 \mathrm{~mL}$ of whey was collected and centrifuged $\left(4000 \times g, 10 \mathrm{~min}, 4^{\circ} \mathrm{C}\right)$. The cell free supernatant was stored at $-80^{\circ} \mathrm{C}$ in order to examine the extracellular - secreted protease (E) activity. The remainder of the fermented milk was adjusted to $\mathrm{pH} 7.0$ with $1 \mathrm{M}$ $\mathrm{NaOH}$, and cleared by adding $10 \%$ trisodium citrate. The cells $\left(\mathrm{OD}_{600} \approx 1.75\right)$ were harvested by centrifugation $\left(4000 \times g, 20 \mathrm{~min}, 4^{\circ} \mathrm{C}\right)$ and the pellet was washed with $0.05 \mathrm{M}$ Tris- $\mathrm{HCl} \mathrm{pH} 7.0$ at $4^{\circ} \mathrm{C}$. To release the cell envelope proteinase (CEP), the cells from $100 \mathrm{~mL}$ fermented milk were resuspended in $2 \mathrm{~mL}$ of $0.05 \mathrm{M}$ Tris$\mathrm{HCl} \mathrm{pH} 7.5$ to obtain cell density $\mathrm{OD}_{600} \approx 24$, where 1 of $\mathrm{OD}_{600}$ corresponds to $2 \mathrm{mg}$ of dry weight of biomass. The cell suspension was incubated at $32^{\circ} \mathrm{C}$ for $1 \mathrm{~h}$ under constant stirring and then centrifuged $(4000 \times g, 20 \mathrm{~min}$, $\left.4^{\circ} \mathrm{C}\right)$. The supernatant, designated as crude CEP, was stored at $-80^{\circ} \mathrm{C}$.

The cell growth in skim milk was evaluated by measuring cell density $\left(\mathrm{OD}_{600}\right)$ of clarified samples. Cell clarification was performed by an EDTA-borate treatment (Christensen \& Steele, 2003).

The protein concentration in the crude enzyme was determined by the bicinchoninic acid (BCA) protein assay, using bovine serum albumin (BSA) as a standard.

Protease enzyme activity. Enzyme activity was measured by a modified method described by Harding et al. (1949). The assay mixture contained $1 \mathrm{~mL}$ of $2.5 \%$ (w/v) azocasein, $0.6 \mathrm{~mL}$ of $50 \mathrm{mM}$ Tris- $\mathrm{HCl} \mathrm{pH} 7.5$ and $0.4 \mathrm{~mL}$ of enzyme. After $60 \mathrm{~min}$ incubation at $37^{\circ} \mathrm{C}$ under constant stirring (600 rpm), $1 \mathrm{~mL}$ of sample was collected and added to $4 \mathrm{~mL}$ of $5 \%(\mathrm{v} / \mathrm{v})$ TCA. Next, the sample was filtered with a $0.45 \mu \mathrm{m}$ pore size filter (Millipore). $1 \mathrm{~mL}$ of the filtrate was mixed with $3 \mathrm{~mL}$ of $0.5 \mathrm{M} \mathrm{NaOH}$. Release of the azo dye was detected by measuring absorbance at $440 \mathrm{~nm}$. Endopeptidase activity was calculated with the following equation:

$\Delta A=A_{\text {sample }}-A_{\text {blank }}$

where:

$A_{\text {sample }}$ - absorbance of the test sample

$A_{\text {blank }}$ - absorbance of blank, without enzyme.

One unit [1U] of endopeptidase activity was defined as the amount of enzyme that caused an increase of 0.01 at $\mathrm{A}_{440}$ under the assay conditions.

Zymography analysis. Identification of enzymes from E. faecalis was carried out by native gel electrophoresis using a $10 \%$ resolving gel copolymerized with $2.5 \%(\mathrm{w} / \mathrm{v})$ azocasein. Crude enzymes were concentrated by ultrafiltration with Amicon Ultra-15 centrifugal filter with a nominal molecular weight of $10 \mathrm{kDa}$. The fraction of molecular weight $\geq 10 \mathrm{kDa}$ was applied on the gel and electrophoresis was performed at a constant voltage of $100 \mathrm{~V}$ per gel at $4^{\circ} \mathrm{C}$. After electrophoresis, the gel was incubated in zymography-developing buffer for $18 \mathrm{~h}$ at $37^{\circ} \mathrm{C}$. The gel was stained by using $0.5 \%$ solution of amido black in methanol-glacial acetic acid-water (5:1:4). Destaining was carried out using an aqueous solution of $30 \%$ methanol and $10 \%$ acetic acid. Protein bands with protease activity were revealed as clear zones on a dark background.

Partial purification and characterization of $E$. faecalis CEP

Precipitation. Crude CEP was subjected to 14,30 and $55 \%$ saturated ammonium sulfate precipitation at $4^{\circ} \mathrm{C}$. After each step, the solution was stirred for $25 \mathrm{~min}$ and the precipitate collected by centrifugation $(4000 \times g$, $\left.20 \mathrm{~min}, 4^{\circ} \mathrm{C}\right)$. The pellets were suspended in $50 \mathrm{mM}$ Tris- $\mathrm{HCl} \mathrm{pH}$ 7.5. The enzyme activity and the protein concentration were monitored at each step of purification as mentioned above.

Diafiltration. The $30-55 \%$ precipitate fraction (the highest activity) was dialysed against distilled water using the Amicon Ultra-15 centrifugal filter $(10 \mathrm{kDa})$. 
Gel-filtration chromatography. The dialysate fraction precipitated with $30 \%$ ammonium sulfate was subjected to gel chromatography with ÄKTA Explorer 100 Air (Amersham Pharmacia, Sweden). The samples were applied to a HiLoad 26/60 Superdex 75 column and eluted with an isocratic system using a $50 \mathrm{mM}$ phosphate buffer $\mathrm{pH} 7.12$ containing $0.15 \mathrm{M} \mathrm{NaCl}$, at a flow rate of $1.0 \mathrm{~mL} / \mathrm{min}$. The injection volume of the sample was $11 \mathrm{~mL}$. The wavelength of the UV/Vis detector was set at $280 \mathrm{~nm}$. The fractions were pooled and concentrated using the Amicon Ultra-15 centrifugal filter (with a nominal molecular weight of $10 \mathrm{kDa}$ ) for measurement of proteolytic activity.

Effect of temperature and $\mathrm{pH}$ on the proteases activity. D-optimal design of response surface methodology (RSM) was used to determine optimum conditions (temperature and $\mathrm{pH}$ ) for protease activity. Design-Expert 9.0 (Stat-Easa, Inc., USA) was used for the assay design and statistical analysis. Effects of $\mathrm{pH}$ (variable code: $\mathrm{X}_{1}$ ) and temperature (variable code: $\mathrm{X}_{2}$ ) on the CEP protease activity were investigated at five different levels, coded as $-1,-0.5,0,+0.5$ and +1 . The design consisted of two factors $\left(\mathrm{X}_{1}, \mathrm{X}_{2}\right)$ at five equidistant levels $\left(37,41,45,49\right.$ and $\left.53{ }^{\circ} \mathrm{C}\right)$ for $\mathrm{X}_{1} ; 6.0,6.5,7.0,7.5$ and 8.0 for $\mathrm{X}_{2}$. The level chosen was based on results of single-factor experiments.

Enzyme activity (variable code: $\mathrm{Y}_{1}$ ) was measured during the D-optimal experiment using $4 \%(\mathrm{w} / \mathrm{v})$ whey protein concentrate (WPC-80) solution as substrate for $8 \mathrm{~h}$. WPC-80 solutions were prepared in appropriate buffers (0.1 $\mathrm{M}$ phosphate buffer in the range of $\mathrm{pH}$ 6.0-7.5 and $0.1 \mathrm{M}$ Tris- $\mathrm{HCl}$ for $\mathrm{pH} 8.0$ ) and then heated for 30 min at $65^{\circ} \mathrm{C}$ (Costa et al., 2007). Samples were incubated under assay conditions and then the degree of proteolysis was measured by the OPA method. $15 \mu \mathrm{L}$ of samples were added to $1 \mathrm{~mL}$ of the OPA reagent and after 2 min incubation at ambient temperature, the absorbance was measured at $340 \mathrm{~nm}$. The result was expressed as the difference in absorbance between the hydrolysed WPC-80 and control (unhydrolysed WPC-80).

Enzyme specificity. Endopeptidase activity was measured in terms of azocasein as a substrate. Samples were examined by the method described under "Protease enzyme activity" chapter.

Samples for aminopeptidase assay contained $50 \mu \mathrm{L}$ of (6 mg/mL) L-leucine-pNa, $1.8 \mathrm{~mL}$ of $50 \mathrm{mM}$ Tris- $\mathrm{HCl}$ $\mathrm{pH} 7.5$ and $0.2 \mathrm{~mL}$ enzyme. Samples were incubated at $37^{\circ} \mathrm{C}$ for $90 \mathrm{~min}$ under constant stirring. The release of $p$-nitroaniline $(\mathrm{pNa})$ was detected by absorbance at $410 \mathrm{~nm}$. One unit [1 U] of aminopeptidase activity was defined as the amount of enzyme required to liberate $1 \mathrm{nM}$ of $\mathrm{pNa}$ per $1 \mathrm{~min}$ under the assay conditions. The amount of relesed $\mathrm{pNa}$ was determined by calibration curve prepared using standard concentrations of $\mathrm{pNa}$. Specific activity was expressed as units per $\mathrm{mg}$ protein of the crude enzyme.

The ability to hydrolyse whey proteins was measured in terms of $4 \%(\mathrm{w} / \mathrm{v})$ WPC-80 solutions released by dissolving in $0.1 \mathrm{M}$ phosphate buffer $\mathrm{pH} 7.0$ and then heated for $30 \mathrm{~min}$ at $65^{\circ} \mathrm{C}$ (Costa et al., 2007). The WPC-80 hydrolysis was carried out under optimal $\mathrm{pH}$ and temperature for CEP activity with the substrate $v$ s. enzyme ratio of $5: 1$, at $37^{\circ} \mathrm{C}$ for $24 \mathrm{~h}$. Hydrolysis was stopped by heating in a boiling water bath for $5 \mathrm{~min}$. Samples were centrifuged $\left(4500 \times g, 10 \mathrm{~min}, 4^{\circ} \mathrm{C}\right)$ and supernatants were stored at $-20^{\circ} \mathrm{C}$ for further analysis. The degree of hydrolysis $(\mathrm{DH})$ was measured using the OPA method and the DH percentage was calculated with the following equation (Spellman et al., 2003):
$\mathrm{DH}(\%)=\underline{\Delta A \times 1.934 \times d}$

where:

$\triangle A$ is $A_{340}$ of the test sample $-A_{340}$ unhydrolysed sample $d$ - dilution factor

$c-$ protein concentration $(\mathrm{mg} / \mathrm{mL})$.

Additionally, the assessment of whey proteins degradation during enzymatic hydrolysis was monitored by electrophoresis. For this purpose, supernatants were lyophilized and stored at $-20^{\circ} \mathrm{C}$. Before applying on the gel, samples were dissolved in $0.5 \mathrm{M}$ Tris-HCl buffer $\mathrm{pH}$ 6.8. SDS-PAGE was performed by the method described below using 15\% gel. Degradation of whey proteins was observed as the reduction in the band intensity during hydrolysis with respect to the original intensity of unhydrolysed proteins.

Determination of molecular mass. Molecular mass of the protease was evaluated by SDS-PAGE using 12\% gel, according to standard procedure (Laemmli, 1970). The gel was stained with $0.1 \%$ solution of Coomassie Brilliant Blue R-250 in methanol-glacial acetic acid-water (5:2:5). Distaining was carried out using an aqueous solution of $30 \%$ methanol and $10 \%$ acetic acid. Unstained Protein Molecular Weight Marker was used as molecular weight standard.

Identification of proteases by LC-MS-MS/MS. The E and CEP of E. faecalis were analyzed by liquid chromatography coupled to the mass spectrometer (LCMS-MS/MS) in the Laboratory of Mass Spectrometry, Institute of Biochemistry and Biophysics, Polish Academy of Sciences (Warsaw, Poland).

Samples were concentrated and desalted on a RP-C18 pre-column (Waters), and further peptide separation was achieved on a nano-Ultra Performance Liquid Chromatography (UPLC) RP-C18 column (Waters, BEH130 C18 column, $75 \mu \mathrm{m}$ i.d., $250 \mathrm{~mm}$ long) of a nanoACQUITY UPLC system, using a 45 min linear acetonitrile gradient. Column outlet was directly coupled to the Electrospray ionization (ESI) ion source of the Orbitrap Velos type mass spectrometer (Thermo), working in the regime of data dependent MS to MS/MS switch with HCD type peptide fragmentation. An electrospray voltage of $1.5 \mathrm{kV}$ was used. Raw data files were pre-processed with Mascot Distiller software (version 2.4.2.0, MatrixScience). The obtained peptide masses and fragmentation spectra were matched to the MEROPS peptide database using the Mascot search engine (Mascot Daemon v. 2.4.0, Mascot Server v. 2.4.1, MatrixScience).

Protein identification was performed using the Mascot search engine (MatrixScience), with the probability based algorithm. The expected value threshold of 0.05 was used for analysis.

\section{Detection of potential virulence factors}

DNA isolation. Total bacterial DNA was extracted using Genomic Mini AX Bacteria Kit (A\&A Biotechnology, Gdańsk, Poland). Briefly, bacterial pellet was resuspended in $100 \mu \mathrm{L}$ of Tris buffer. After initial incubation in $50 \mathrm{mg} / \mathrm{mL}$ lysozyme for $1 \mathrm{~h}$ at $37^{\circ} \mathrm{C}, 200 \mu \mathrm{L}$ of Total Lysis buffer and $20 \mu \mathrm{L}$ of Proteinase $\mathrm{K}$ were added. Cell lysis was done at $37^{\circ} \mathrm{C}$ for $20 \mathrm{~min}$, and then the sample was transferred to $70^{\circ} \mathrm{C}$ and incubated for $5 \mathrm{~min}$. Cellular debris was collected by centrifugation for $3 \mathrm{~min}$ at 10000-15000 rpm. Supernatant was transferred into the minicolumn, which was washed twice with Wash Solution A1. DNA was eluted using $100 \mu \mathrm{L}$ of Tris buffer (preheated to $75^{\circ} \mathrm{C}$ ). The quality of the preparations was assessed spectrophotometrically with NanoDrop ND1000 (NanoDrop Technologies, Inc., USA). 
PCR amplification of selected genes. The presence of genes encoding selected virulence factors $(c y l A$, esp, asa1, byl, gelE) in the genome of E. faecalis was assessed by multiplex PCR according to the methods of Vankerckhoven and others (Vankerckhoven et al., 2004). The DNA from E. faecalis MMH594.1 was used as a reference sample (positive control). PCR was performed in total volume of $10 \mathrm{uL}$ containing $5 \mathrm{uL}$ StartWarm $2 \times$ PCR Master Mix with additional $\mathrm{MgCl}_{2}(2.5 \mathrm{mM}), 25 \mathrm{ng}$ DNA template, $0.1 \mu \mathrm{M}$ concentration of each primer specific for asa1, gelE and byl; and $0.2 \mu \mathrm{M}$ concentration of each primer specific for $c y l A$ and esp. PCR was carried out with the $T$ Gradient Thermocycler (Biometra, Germany). After initial activation step at $95^{\circ} \mathrm{C}$ for $10 \mathrm{~min}$, the hot start polymerase was activated. The amplification of selected genes consisted of 30 cycles of 1 min denaturation step at $94^{\circ} \mathrm{C}, 1 \mathrm{~min}$ annealing step at $56^{\circ} \mathrm{C}$, and 1 min extension at $72^{\circ} \mathrm{C}$. Negative controls containing no DNA template were included in parallel. $10 \mu \mathrm{L}$ samples of PCR product were analyzed by electrophoresis in $2.0 \%(\mathrm{w} / \mathrm{v})$ agarose in $1 \times$ TBE buffer $(89 \mathrm{mM}$ Trisborate; 2 mM EDTA, $\mathrm{pH}$ 8.3) and were subsequently visualized by UV illumination after ethidium bromide staining.

Sensitivity to antibiotics. Antibiotic susceptibility test of E. faecalis was carried out with the following antibiotics: penicillin $10 \mathrm{IU}$, ampicillin $10 \mathrm{mg}$, gentamicin $30 \mathrm{ug}$, streptomycin $10 \mathrm{ug}$, vancomycin $30 \mathrm{mg}$, imipenem $10 \mathrm{mg}$, erythromycin $15 \mathrm{mg}$, tetracycline $30 \mathrm{mg}$, chloramphenicol $30 \mu \mathrm{g}$ and rifampicin $5 \mu \mathrm{g}$, by the disk diffusion method on Mueller-Hinton agar plates. Classification of $E$. faecalis susceptibility was made according to the inhibition zone diameter, based on The National Reference Centre for Susceptibility Testing (Hryniewicz et al., 2012).

Statistical analysis. All of the experiments were made in triplicate and data was expressed as means \pm standard deviation (S.D.).

\section{RESULTS AND DISCUSSION}

The selection of E. faecalis 2/28 for the source of proteolytic enzymes was due to our previous research, which has shown that a lot of LAB strains, originated from artisan Polish cheeses from raw milk produced in the Podhale region, have the proteolytic ability (unpublished data), however E. faecalis 2/28 displayed the most efficient proteolytic activity and it was chosen for further isolation of bacterial proteases.

\section{Biosynthesis of bacterial proteases from $E$. faecalis}

The LAB proteolytic system consists of extracellular, cell envelope and intracellular enzymes, belonging to proteinases and peptidases, respectively (Law \& Mulholland, 1995; Meijer et al., 1996; Law \& Haandrikman, 1997). In this study, the extracellular-secreted (E) and the cell envelope proteases (CEP) were isolated because of their evaluation as the most important enzymes in food production. Taking into account that studies on the effect of bacterial growth phase on proteases activity level are ambiguous (Exterkate, 1985; Laan et al., 1993; Meijer et al., 1996; Pereira et al., 2001), the protease activity of $E$ and CEP and its dependence on bacterial growth phase was evaluated. As shown in Fig. 1, the highest protease activity of $\mathrm{E}$ was detected during the exponential growth phase $(14.0 \pm 0.20 \mathrm{U})$. The maximum activity of CEP was at the initial stationary phase, at approximately 25 $\mathrm{h}$ of milk fermentation $(17.1 \pm 0.42 \mathrm{U})$. These results

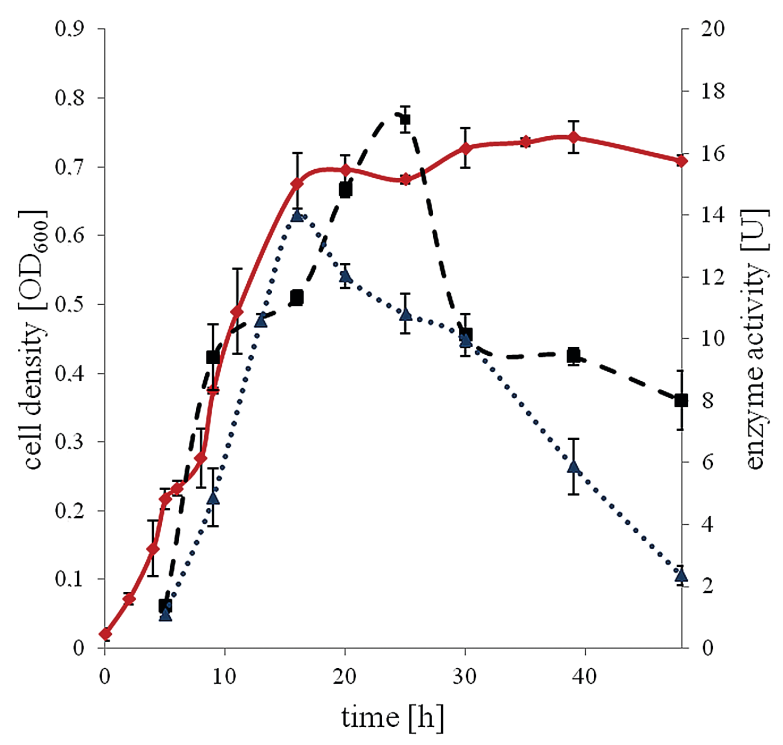

Figure 1. Biosynthesis of extracellular and cell envelope proteinase produced by Enterococcus faecalis during milk fermentation $(-)$ Cell density $\left[\mathrm{OD}_{600}\right] ;(\cdots)$ extracellular enzyme [U]; (- - -) cell envelope proteinase [U]. Assay of enzymatic activity was measured by azocasein. Cell growth during milk fermentation was performed by an EDTA-borate treatment (Christensen \& Steele, 2003) and was then evaluated by measuring cell density $\left(\mathrm{OD}_{600}\right)$.

showed that the specific activity of CEP (20.5 U/mg) was significantly higher than $\mathrm{E}(1.5 \mathrm{U} / \mathrm{mg})$ and it was observed for a longer period during cell growth. The theory of Thomas and Pritchard (Thomas \& Pritchard, 1987) could explain the high activity of enzymes associated with the cell wall. These researchers had stated that this enzyme fraction plays a key role in LAB metabolism, initiating the degradation of milk protein into oligopeptides which are subsequently hydrolyzed to amino acids, i.e. necessary factors for bacterial growth (Meijer et al., 1996).

\section{Zymography analysis}

In order to detected the protease in CEP and the $\mathrm{E}$ crude fractions, concentrated fractions of $\geq 10 \mathrm{kDa}$ in molecular weight proteins were subjected to zymography analysis. Casein zymography was performed in native polyacrylamide gels containing azocasein $(2.5 \%)$ as a copolymerized substrate. The zymography analysis indicated that the tested protein fractions (CEP and E) contain

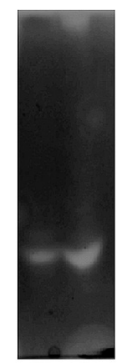

Figure 2. Zymogram of cell envelope proteinase (CEP) and extracellular-secreted protease (E)

Zymography was performed with native polyacrylamide gels containing azocasein $(2.5 \%)$, stained with amido black. Clear colorless zones on a dark background gel indicated protease activity. Lane 1, cell envelope proteinase (CEP); lane 2, extracellular-secreted protease (E). 
Table 1. Purification of cell envelope proteinase (CEP) of Enterococcus faecalis

Proteolytic activity was measured by azocasein. The protein concentration was determined by the bicinchoninic acid (BCA) protein assay.

\begin{tabular}{|c|c|c|c|c|c|}
\hline Purification step & Volume $[\mathrm{mL}]$ & Total protein [mg] & Total activity [U] & Specific activity [U/mg] & Purification (fold) \\
\hline Crude enzyme & 172 & 715 & 14693.1 & 20.5 & 1.0 \\
\hline Ammonium sulphate precipitation & 22.19 & 115.4 & 3292.4 & 28.5 & 1.4 \\
\hline Diafiltration & 3.6 & 24.8 & 1614.6 & 65.1 & 3.2 \\
\hline Superdex 200 + UF (30 kDa) & 1.06 & 0.22 & 343.8 & 1448.8 & 70.7 \\
\hline
\end{tabular}

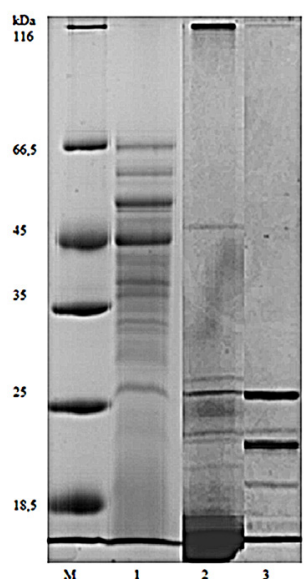

Figure 3. SDS-PAGE for the cell envelop proteinase (CEP) of Enterococcus faecalis

SDS-PAGE analysis was performed at different purification steps using $12 \%$ polyacrylamide gel, stained with Coomassie Blue. Lane

1, crude CEP; lane 2, CEP after precipitation and diafiltration; lane 3. CEP after gel filtration chromatography ( $P 1$ fraction); lane $M$, molecular weight marker (Unstained Protein Molecular Weight Marker).

active proteases, which was observed as a clear colorless zones on a dark background (Fig. 2).

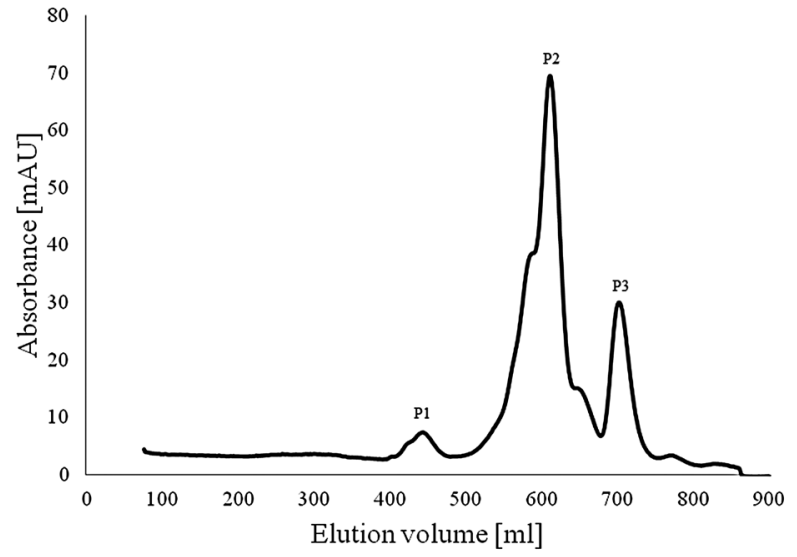

Figure 4. Gel filtration of the $\mathbf{3 0}-\mathbf{5 5} \%$ precipitate fraction Gel filtration chromatography was performed on HiLoad 26/60 Superdex 75 column. P1, P2, P3 - separated fractions.

\section{Partial purification and characterization of $E$. faecalis CEP}

Based on preliminary results of the enzyme activity, the CEP fraction was used for further analysis. The E. faecalis CEP was partially purified using 3 steps: precipitation, diafiltration and gel-filtration chromatography. A purification scheme, which resulted in a 70 -fold puri-

Table 2. Results of D-optimal design of RSM

Conditions of experiments ( $\mathrm{X}_{1}: \mathrm{pH}, \mathrm{X}_{2}$ :temperature) were determined by D-optimal design of RSM. Enzyme activity was tested by $4 \%$ ( $\mathrm{w} / \mathrm{v}$ ) whey protein concentrate (WPC-80) solution.

\begin{tabular}{|c|c|c|c|}
\hline \multirow{2}{*}{ Variant of the experiment } & \multicolumn{3}{|c|}{ Variable } \\
\hline & $\mathrm{x}_{1}: \mathrm{pH}$ & $\mathrm{X}_{2}:$ Temperature $\left[{ }^{\circ} \mathrm{C}\right]$ & $Y_{1}$ : Enzyme activity \\
\hline 1 & 7.5 & 49 & 0.099707 \\
\hline 2 & 6 & 53 & 0.032107 \\
\hline 3 & 7 & 53 & 0.069107 \\
\hline 4 & 8 & 37 & 0.205907 \\
\hline 5 & 7 & 41 & 0.340607 \\
\hline 6 & 6.5 & 49 & 0.152607 \\
\hline 7 & 8 & 45 & 0.159107 \\
\hline 8 & 7 & 45 & 0.310807 \\
\hline 9 & 8 & 37 & 0.332707 \\
\hline 10 & 6 & 45 & 0.173007 \\
\hline 11 & 6 & 37 & 0.334607 \\
\hline 12 & 6 & 53 & 0.003407 \\
\hline 13 & 7 & 45 & 0.193707 \\
\hline 14 & 7 & 37 & 0.344107 \\
\hline 15 & 6 & 37 & 0.275707 \\
\hline 16 & 8 & 53 & 0.034007 \\
\hline
\end{tabular}




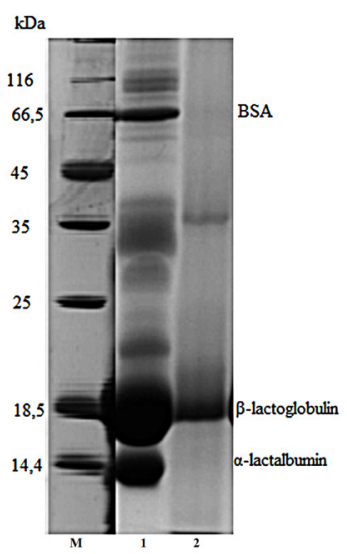

Figure 5. SDS-PAGE of WPC-80 hydrolysate obtained after treating WPC-80 with CEP of Enterococcus faecalis

SDS-PAGE analysis was performed with $15 \%$ polyacrylamide gel, stained with Coomassie Blue. Lane $M$, molecular weight marker (Unstained Protein Molecular Weight Marker; 14.4-116 kDa); lane 1 , native WPC-80; lane 2, WPC-80 hydrolyzed by CEP for $24 \mathrm{~h}$.

fication, was developed. The results are summarized in Table 1.

CEP were analyzed at different purification steps by SDS-PAGE (Fig. 3). After the final purification step, four protein bands were detected in the pooled active P1 fraction (Fig. 4) with a molecular mass which ranged from 25 to $18.5 \mathrm{kDa}$. A similar result was reported by Garcia de Fernando and others (Garcia de Fernando et al., 1991), who investigated the extracellular protease produced by E. faecalis subsp. liquefaciens, and demonstrated that the molecular mass of the enzyme was $\sim 26 \mathrm{kDa}$ by SDS PAGE and $\sim 30 \mathrm{kDa}$ by Sephadex gel filtration.

\section{Effect of $\mathrm{pH}$ and temperature}

D-optimal design of RSM was used to determine the optimal conditions for enzyme activity. Table 2 shows the results of experiments. The tested crude CEP showed maximum activity at $37^{\circ} \mathrm{C}$, while optimum $\mathrm{pH}$ was 6.9.

\section{Enzyme specificity}

In this study, enzyme specificity of CEP was evaluated by measurement of endopeptidase and aminopeptidase activity by using azocasein and L-leucine-pNa as substrates, respectively. CEP was able to hydrolyze azocasein, but did not show activity against Leu-pNa. The

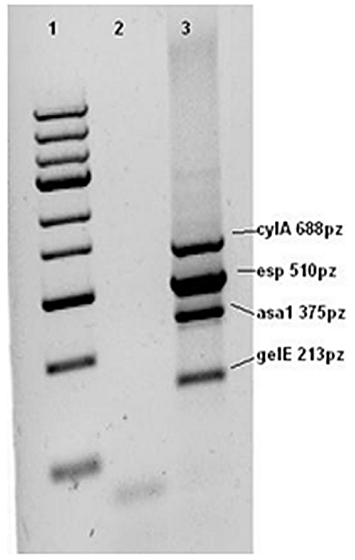

Figure 6. Multiplex PCR of Enterococcus faecalis

Lane 1, molecular weight marker (GeneRuler Express DNA Ladder, bands: 5000, 3000, 2000, 1500, 1000, 750, 500, 300, 100,); lane 2, negative control (no DNA added); lane 3, Enterococcus faecalis.

endopeptidase activity level was $17.1 \mathrm{U}$ and the aminopeptidase activity level was not observed.

The ability of proteases from E. faecalis 2/28 to hydrolyse whey proteins was also evaluated. It was shown that CEP have the ability to hydrolyze WPC-80. The degree of hydrolysis after $24 \mathrm{~h}$ equaled $20.3 \%$. In order to evaluate the degradation of whey proteins during enzymatic hydrolysis, electrophoresis was carried out. SDSPAGE showed distribution of whey protein during enzymatic hydrolysis. As shown by electropherogram (Fig. 5), after $24 \mathrm{~h}$ hydrolysis, serum albumin and $\alpha$-lactalbumin were degraded altogether while the degradation of $\beta$-lactoglobulin was significant but not full. This is in line with results obtained by Garcia de Fernando and others (Garcia de Fernando et al., 1991), who demonstrated that the extracellular protease produced by E. faecalis subsp. liquefaciens was able to hydrolyze casein, $\alpha$-lactoalbumin, $\beta$-lactoglobulin and bovine serum albumin.

Whey proteins are considered to be substrates resistant to enzymatic hydrolysis (Babij et al., 2013; Spellman et al., 2003). The use of commercial enzymes for their proteolysis often does not give satisfactory results. The results of the study present here indicate that proteases from E. faecalis $2 / 28$ exhibit proteolytic activity towards whey proteins, which could imply their potential application in the dairy technology and biotechnology, e.g. biopeptide production.

Table 3. Sensitivity of Enterococcus faecalis to selected antibiotics Sensitivity to antibiotics was performed by the disk diffusion method on Mueller-Hinton agar plates using standard Antimicrobial Susceptibility test discs (Oxoid).

\begin{tabular}{|c|c|c|c|}
\hline Antibiotic & Dose of antibiotic & Inhibition zone diameter (mm) & Sensitive $(+) /$ lack of sensitive $(-)$ \\
\hline Penicillin & $10 \mathrm{IU}$ & 18 & + \\
\hline Ampicillin & $10 \mu \mathrm{g}$ & 14 & + \\
\hline Gentamicin & $30 \mu \mathrm{g}$ & 14 & + \\
\hline Streptomycyn & $10 \mu \mathrm{g}$ & - & - \\
\hline Vancomycin & $30 \mu \mathrm{g}$ & 16 & + \\
\hline Imipenem & $10 \mu \mathrm{g}$ & 30 & + \\
\hline Erythromycin & $15 \mu \mathrm{g}$ & - & - \\
\hline Tetracycline & $30 \mu \mathrm{g}$ & - & - \\
\hline Chloramphenicol & $30 \mu \mathrm{g}$ & 10 & + \\
\hline Rifampicin & $5 \mu g$ & 14 & + \\
\hline
\end{tabular}




\section{Identification of proteases by LC-MS-MS/MS}

Protease expression is strain specific and it is not representative for the whole species of Enterococcus faecalis (Pessione et al., 2012). Thus, in order to identify the proteases of the CEP fraction, i.e. the key enzymes for proteolytic system of the tested strain, LC-MS-MS/MS analysis was performed. Based on the results of zymography and SDS PAGE, together with MS/MS data and literature information (Garcia de Fernando et al., 1991; Pei-Show, 2002), it revealed that the key enzymes of proteolytic system of $E$. faecalis $2 / 28$ are coccolysin (gelatinase) and glutamyl endopeptidase.

Gelatinase (GelE) and glutamyl endopeptidase (serine proteinase V8, SprE) are extracellular proteases. Their respective encoding genes, gelE and sprE, are located in the same operon and are co-transcribed (Pessione et al., 2012). They are known as toxic substances secreted by Enterococcus strains which have a destructive effect on the host's tissues. GelE has been also reported to contribute to bacterial adherence and biofilm formation (Anderson et al., 2016; Chajęcka-Wierzchowska et al., 2017; Franz et al., 2003). On the other hand, there is evidence that proteases from enterococci could find potential application in the processing of some dairy products. According to Giraffa (Giraffa, 2003), the presence of enterococci as non-starter LAB or added as adjunct starter throughout ripening of cheeses, positively affected their taste, aroma, structure and color. This seemed linked to the fact that in the cheeses made with enterococci, total free amino acids, soluble nitrogen, long-chain free fatty acids, volatile free fatty acids and acetoin diacetyl and contents were generally higher, as the result of bacterial enzymatic activity. Recent research also suggested that the gelatinase may have interesting biotechnological traits, e.g. production of bioactive peptides (Gútiez et al., 2013).

\section{Detection of potential virulence factors}

Enterococci have a beneficial effect in the dairy food production and a long history of safe use, however, they are characterized by natural resistance to numerous antibiotics. Some Enterococcus strains isolated from food also carry virulence factors typical for nosocomial pathogens, such as ace, asa1, gelE, and esp (Chajęcka-Wierzchowska et al., 2017; Pessione et al., 2012). Nevertheless, there are no legal regulations that would allow to exclude those strains which may cause infections, from the use in the industry.

In view of the above, in this study, the evaluation of E. faecalis properties which are relevant in biotechnology was carried out with respect to their potential pathogenicity as well. Taking into account that virulence in the Enterococcus genus has been considered as a multifactor process, with participation of several genes and their products (Eaton \& Gasson, 2001; Vankerckhoven et al., 2004; Kawalec \& Jakubczak, 2006), the genome of Enterococcus faecalis was examined for the presence of genes encoding selected virulence factors (cylA, esp, asa1, gelE, byl).

The analysis showed that E. faecalis was positive for cylA, esp, asa1, gelE genes encoding cytolysin, enterococcal surface protein, aggregation substance and gelatinase (coccolysin), respectively, but the byl gene encoding hyaluronidase was not detected (Fig. 6). Accordingly, the analyzed strain lacks gene for hyaluronidase which is believed to contribute to invasion of the nasopharynx and to pneumonia.

Other research also proved that strains isolated from food may possess virulence determinants (Cariolato et al., 2008; Eaton \& Gasson, 2001 and Gútiez et al., 2013; Medeiros et al., 2014). For example, Medeiros and others (Medeiros et al., 2014) compared strains isolated from food and from material of clinical origin and showed that regardless of the source of isolation, the incidence of the gelatinase gene (gelE) and the collagen binding protein (ace) is at the same level. Cariolato and others (Cariolato et al., 2008) noted that virulence factors were present in both, the dairy and human strains, and had shown that E. faecalis strains isolated from dairy products have from 1 to 6 virulence factors in their genome. More importantly, Domann and others (Domann et al., 2007) pointed out that both, asa1 and esp, are equally present in the commercial probiotic strain of E. faecalis Symbioflor1. On the other hand, Eaton and Gasson (Eaton \& Gasson, 2001) revealed that the frequency of occurrence of virulence determinants is higher among hospital isolates than strains derived from food. In contrast, Anderson and others (Anderson et al., 2015) demonstrated that the food isolates possessed more asa 1 and esp genes than the clinical isolates, and also possessed more esp and gelE genes than the food isolates studied by Eaton and Gasson (Eaton \& Gasson, 2001). Anderson and others (Anderson et al., 2015) suggested that a high percentage of these virulence factors is reported for isolates originated from raw milk.

However, the role of some virulence factors, such as aggregation substances, adhesions, gelatinase, or cytolysin in enterococcal pathogenicity is unclear. For example, the gelatinase and the serine proteinase V8 have been described as major virulence factors of the Enterococcus genus (Qin et al., 2000; Thurlow et al., 2010). On the other hand, high frequency of gelE gen occurrence in the genome of strains isolated from dairy food, may suggest that gelatinase has an important function in the metabolism of these bacteria (Anderson et al., 2015; Medeiros et al., 2014). Moreover, enterococci are also capable to produce bacteriocins, such as cytolysin and enterolysin, with activity against Listeria monocytogenes, Staphylococcus aureus, Clostridium botulinum or Vibrio cholerae and can be used as probiotics (Giraffa, 2003). The presence of the ace and esp genes encoding adhesins, is seen by many researchers as one of the factors having important roles in the early stages of infection and facilitating colonization of the host (Shankar et al., 2001; Gilmore et al., 2002). In contrast, Archimbaud and others (Archimbaud et al., 2002) found no link between the presence of gelatinase, cytolysin and aggregation substance, and the ability of $E$. faecalis strains to adhere to heart cells in an in vitro study.

\section{Sensitivity to antibiotics}

Clinical importance of bacteria of the Enterococcus genus is directly related to their natural antibiotic resistance, e.g. to cephalosporins, cotrimoxazol or clindamycin (Hryniewicz et al., 2012) and their ability to transfer resistance genes to other microorganisms (Ortigosa et al., 2008), which contributes to the risk of infection. In the light of the above, the susceptibility to antibiotics of the tested strain was determined. The selection of antibiotics for susceptibility testing was in accordance to the recommendation of The National Reference Centre for Susceptibility Testing (Hryniewicz et al., 2012). On the basis of the antibiograms provided, it was shown that the tested strain was susceptible to penicillin, ampicillin and gentamycin, i.e. the first-line antibiotic treatments of infections caused by bacteria of the Enterococcus genus. The tested strain was also susceptible to vancomycin, imipenem, chloramphenicol and rifampicin, i.e. medicines that 
are intended for treatment of infections caused by multidrug-resistant enterococci. However, the tested strain was resistant to streptomycin, tetracycline, and erythromycin, i.e. antibiotics indicated as add-on therapy of enterococcal infections. The results of the antibiotic susceptibility of $E$. faecalis are presented in Table 3.

The resistance of E. faecalis to streptomycin is probably dependent on the antibiotic dose used. The recommended concentration of streptomycin for the treatment of enterococcal infections is $300 \mu \mathrm{g}$ and in this study a dose of $10 \mu \mathrm{g}$ was used. However, the sensitivity to vancomycin is of particular clinical importance because vancomycin belongs to the group of glycopeptides considered as the last line of defence for patients who suffer from opportunistic infections.

According to some researchers, the pathogenic potential of enterococci is small as evidenced by their presence as part of the normal microflora of gastrointestinal tract, as well as a long history of safe use as starter cultures and probiotics (Franz et al., 2003; Semedo et al., 2003). In fact, enterococci from food, which are carriers of virulence genes, very rarely cause disease in healthy people, which seems to confirm this thesis. Nevertheless, it should be remembered that enterococci have different mechanisms of gene transfer, hence there is a risk of transferring antibiotic resistance genes and virulence genes to other microorganisms (Franz et al., 2003). These data indicate that assessment of sensitivity of enterococci to drugs should be obligatory in this kind of research.

\section{CONCLUSION}

As shown in this study, E. feacalis is able to produce active protease which indicates a possibility of its application in the dairy industry, e.g. to support the breakdown and release of bioactive peptides from whey protein. We also demonstrated that the E. faecalis strain was positive for $y l A$, esp, asa1, gelE genes. Nevertheless, it should be pointed out that the risk assessment on the basis of virulence factors is a problem because the knowledge regarding the type and combination of virulence factors, which are decisive for pathogenic potential, is limited. To our knowledge, there are no legal regulations on the safety of E. faecalis use as a starter cultures or even as a probiotics. Moreover, some of the requirements for probiotics, such as: ability to adhere to cells or produce bacteriocins antagonistic to pathogens, make the same factors responsible for both, the virulence and health benefits, e.g. adhesions.

Furthermore, there is no evidence showing a direct relationship with the consumption of food containing Enterococcus strains harboring some virulence factors and diseases, but the use of enterococci for food production gives rise to controversies. Some researchers believe that virulence of enterococci is mild because in most cases these pathogens usually cause infections in patients who are debilitated by other illnesses and undergoing prolonged hospitalization (Kawalec \& Jakubczak, 2006; Arias \& Murray, 2012).

\section{Acknowledgements}

The authors thank to the Laboratory of Mass Spectrometry, Institute of Biochemistry and Biophysics, Polish Academy of Sciences (Warsaw, Poland) for help with proteomic analyses - MS and protein identification. We thank to dr hab. Anna Sip for providing the LAB strainswhich were used in this study.

\section{REFERENCES}

Anderson AC, Jonas D, Huber I, Karygianni L, Wölber J, Hellwig E, Arweiler N, Vach K, Wittmer A, Al-Ahmad A (2015) Enterococcus faecalis from food, clinical specimens, and oral sites: prevalence of virulence factors in association with biofilm formation. Front Microbiol 6: 1534. https://doi.org/10.3389/fmicb.2015.01534

Allen SJ, Martinez EG, Gregorio GV, Dans LF (2010) Probiotics for treating acute infectious diarrhoea. Cochrane Database of Syst Rev 11, CD003048. https://doi.org/10.1002/14651858.CD003048.pub3

Archimbaud C, Shankar N, Forestier C, Baghdayan A, Gilmore MS, Charbonné F, Joly B (2002) In vitro adhesive properties and virulence factors of Enterococcus faecalis strains. Res Microbiol 153: 75-80. https://doi.org/10.1016/S0923-2508(01)01291-8

Arias CA, Murray BE (2012) The rise of Enterococcus: beyond vancomycin resistance. Nat Rev Microbiol 10: 266-278. https://doi. org $/ 10.1038 /$ nrmicro2761

Babij K, Dąbrowska A, Szołtysik M, Pokora M, Zambrowicz A, Chrzanowska J (2014) The evaluation of dipeptidyl peptidase (DPP)-IV, a-glucosidase and angiotensin converting enzyme (ACE) inhibitory activities of whey proteins hydrolyzed with serine protease isolated from Asian Pumpkin (Cucurbita ficifolia). Int J Pept Res Ther 20: 483491. https://doi.org/10.1007/s10989-014-9413-0

Broadbent JR, Steele JL (2007) Proteolytic enzymes of lactic acid bacteria and their influence on bitterness in bacterial-ripened cheeses. Flavor of Dairy Products 11: 193-203. https://doi.org/10.1021/bk2007-0971.

Bruinenberg PG, Vos P, De Vos WM (1992) Proteinase overproduction in Lactococcus lactis strains: regulation and effect on growth and acidification in milk. Appl Environ Microb 58: 78-84

Cariolato D, Andrighetto C, Lombardi A. (2008) Occurrence of virulence factors and antibiotic resistances in Enterococcus faecalis and Enterococcus faecium collected from dairy and human samples in North Italy. Food Control 19: 886-892. https://doi.org/10.1016/j.foodcont.2007.08.019

Chajęcka-Wierzchowska W, Zadernowska A, Laniewska-Trokenheim Ł (2017) Virulence factors in Enterococcus spp. presented in food. Food Sci Technol 75: 670-676. https://doi.org/10.1016/j.lwt.2016.10.026

Christensen JE, Steele JL (2003) Impaired growth rates in milk of Lactobacillus helveticus peptidase mutants can be overcome by use of amino acid supplements Supplements. J Bacteriol 185: 3297-3306. https://doi.org/10.1128/JB.185.11.3297-3306.2003

Church FC, Swaisgood HE, Porter DH, Catignani GL (1983) Spectrophotometric assay using o-phthaldialdehyde for determination of proteolysis in milk and isolated milk proteins. J Dairy Sci 66: 12191227. https://doi.org/10.3168/jds.S0022-0302(83)81926-2

Costa EL, Rocha Gontijo JAR, Netto FM (2007) Effect of heat and enzymatic treatment on the antihypertensive activity of whey protein hydrolysates. Int Dairy J 17: 632-640. https://doi.org/10.1016/j. idairyj.2006.09.003

Del Papa MF, Hancock LE, Thomas VC, Perego M (2007) Full Activation of Enterococcus faecalis gelatinase by a c-terminal proteolytic cleavage. J Bacteriol 189: 8835-8843. https://doi.org/10.1128/ JB.01311-07

Domann E, Hain T, Ghai R, Billion A, Kuenne C, Zimmermann K, Chakraborty T (2007) Comparative genomic analysis for the presence of potential enterococcal virulence factors in the probiotic Enterococcus faecalis strain Symbioflor 1. Int J Med Microbiol 297: 533-539. https://doi.org/10.1016/j.ijmm.2007.02.008

Eaton TJ, Gasson M (2001) Molecular screening of Enterococcus virulance determinants and potential for genetic exchange between food and medical isolates. Appl Environ Microb 67: 1628-1635. https:// doi.org/10.1128/AEM.67.4.1628-1635.2001

European Committee on Antimicrobial Susceptibility Testing (2017) Breakpoint tables for interpretation of MICs and zone diameters. Version 7.1.

Exterkate FA (1985) A dual-directed control of cell wall proteinase production in Streptococcus cremoris AM1: A possible mechanism of regulation during growth in milk. Int Dairy J 68: 562-571. https:// doi.org/10.3168/jds.S0022-0302(85)80859-6

Foulquie' Moreno MR, Sarantinopoulos P, Tsakalidou E, De Vuyst L (2006) The role and application of enterococci in food and health. Int J Food Microbial 106: 1-24. https://doi.org/10.1016/j.ijfoodmicro.2005.06.026

Franz CM, Stiles ME, Schleifer KH, Holzapfel WH (2003) Enterococci in foods - a conundrum for food safety. Int $J$ Food Microbiol 88: 105-122

Franz CM, Huch M, Abriouel H, Holzapfel W, Gálvez A (2011) Enterococci as probiotics and their implications in food safety. Int $J$ Food Microbiol 15: 125-140. https://doi.org/10.1016/j.ijfoodmicro.2011.08.014

Garcia de Fernando GD, Hernandez PE, Burgos J, San B, Ordoñez JA (1991) Extracellular proteinase from Enterococcus faecalis subsp. liquefaciens: II. Partial purification and some technologically important properties. Folia Microbiol 36: 429-436 
Gilmore MS, Coburn S, Nallapareddy SR, Murray BE (2002) Enterococcal Virulence. In The Enterococci. Pathogenesis, Molecular Biology and Antibiotic Resistance. Gilmore MS, Clewell DB, Courvalin P, Dunny GM, Murray BE, Rice LB eds, pp 301-354. Washington: D.C, ASM PRESS

Giraffa G (2003) Functionality of enterococci in dairy products. Int $J$ Food Microbial 88: 215-222. https://doi.org/10.1016/S01681605(03)00183-1

González L, Sacristán N, Arenas R, Fresno JM, Tornadijo ME (2010) Enzymatic activity of lactic acid bacteria (with antimicrobial properties) isolated from a traditional Spanish cheese. Food Microbiol 27: 592-597. https://doi.org/10.1016/j.fm.2010.01.004

Gútiez L, Gómez-Sala B, Recio I, del Campo R, Cintas LM, Herranz C, Hernández PE (2013) Enterococcus faecalis strains from food, environmental, and clinical origin produce ACE-inhibitory peptides and other bioactive peptides during growth in bovine skim milk. Int J Food Microbial 166: 93-101. https:// doi.org/10.1016/j.ijfoodmicro.2013.06.019

Harding ML, Tomarelli RM, Charney J (1949) The use of azoalbumin as a substrate in the colorimetric determination of peptic and tryptic activity. I Lab Clin Med 34: 428-433

Hernández-Ledesma B, del Mar Contreras M, Recio I (2011) Antihypertensive peptides: Production, bioavailability and incorporation into foods. Adv Colloid Interface Sci 165: 23-35. https://doi.or$\mathrm{g} / 10.1016 /$ i.cis.2010.11.001

Hryniewicz W, Sulikowska A, Szczypa K, Skoczyńska A, Luczak-Kadłubowska A, Gniatkowski M (2012) Recommendations for tests selection for determining the sensitivity of bacteria to antibiotics and chemotherapeutics. The National Reference Centre for Susceptibility Testing, Warszawa (in Polish).

Kawalec M, Jakubczak A (2006) Proteinases of Enterococcus faecalis and their role in pathogenicity. Adv Clin Exp Med 15: 857-869

Kaye DMD (1982) Enterococci: Biologic and epidemiologic characteristics and in vitro susceptibility. Arch Intern Med 142: 2006-2009. https://doi.org/10.1001/archinte.1982.00340240028006

Laan H, Bolhuis H, Poolman B, Abee T, Konings WN (1993) Regulation of proteinase synthesis in Lactococcus lactis. Acta Biotechnol 13: 95-101. https://doi.org/10.1002/abio.370130202

Laemmli UK (1970) Cleavage of structural proteins during the assembly of the head of bacteriophage T4. Nature 227: 680-685. https:// doi.org/10.1038/227680a0

Law J, Mulholland F (1995) Enzymology lactoccoci in relation to flavour development from milk proteins. Int Dairy J 5: 833-854. https://doi.org/10.1016/0958-6946(95)00035-6

Law J, Haandrikman A (1997) Proteolytic enzymes of lactic acid bacteria. Int Dairy J 7: 1-11. https://doi.org/10.1016/09586946(95)00073-9

Lepage E, Brinster S, Caron C, Ducroix-Crepy C, Rigottier-Gois L, Dunny G, Hennequet-Antier C, Serror P (2006) Comparative genomic hybridization analysis of Enterococcus faecalis: Identification of genes absent from food strains. J Bacteriol 188: 6858-6868

Liu M, Bayjanov JR, Renckens B, Nauta A, Siezen RJ (2010) The proteolytic system of lactic acid bacteria revisited: a genomic comparison. BMC genomics. 11: 36. https://doi.org/10.1186/1471-2164-11-36

Mäkinen PL, Clewell DB, An F, Mäkinen KK (1989) Purification and substrate specificity of a strongly hydrophobic extracellular metalloendopeptidase ("gelatinase") from Streptococcus faecalis (OG1-10). J Biol Chem 264: 3325-3334

Medeiros AW, Pereira RI, Oliveira DV, Martins PD, D'azevedo PA, Van der Sand S, Frazzon J, Frazzon APG (2014) Molecular detection of virulence factors among food andclinical Enterococcus faecalis strains in South Brazil. Braz J Microbiol 45: 327-332. https://doi. org/10.1590/S1517-83822014005000031

Meijer W, Marugg JD, Hugenholtz J (1996) Regulation of proteolytic enzyme activity in Lactococcus lactis. Appl Environ Microb 62: 156-161

Mundt OJ (1986) Enterococci. In Bergey's Manual of Systematic Bacteriology, vol. 2. Sneath PHA, Mair NS, Sharpe ME, Holt JG eds, pp 1063-1065. Baltimore: Williams and Wilkins

Murray BE (1990) The life and times of the Enterococcus. Clin Microbiol Rev 3: 46-65. https://doi.org/10.1128/CMR.3.1.46
Official Journal of the European Union (2007) Commission Regulation (EC) No 1441/2007 of 5 December 2007 amending Regulation (EC) No 2073/2005 on microbiological criteria for foodstuffs

Ortigosa M, Irigoyen A, Urdin M, Garcỉa S, Ibañez FC, Torre P (2008): Sources of enterococci in Idiazábal-type cheese. Int J Food Microbiol 125: 146-152. https://doi.org/10.1016/j.ijfoodmicro.2008.03.035

Pei-Show J (2002) Concise Dictionary of Biomedicine and Molecular Biology, pp 293. Boca Raton: CRC Press

Pereira CI, Barreto Crespo MT, San Romao MV (2001) Evidence for proteolytic activity and biogenic amines production in Lactobacillus cuvoatus and L. homohiochii. Int J Food Microbial 68: 211-216. https:// doi.org/10.1016/S0168-1605(01)00534-7

Pessione A, Lamberti C, Cocolin L, Campolongo S, Grunau A, Giubergia S, Eberl L, Riedel K, Pessione E (2012) Different protein expression profiles in cheese and clinical isolates of Enterococcus faecalis revealed by proteomic analysis. Proteomics 12: 431-447. https://doi. org/10.1002/pmic.201100468

Pritchard GG, Coolbear T (1993) The physiology and biochemistry of the proteolytic system in lactic acid bacteria. FEMS Microbiol Rev 12: 179-206. https://doi.org/10.1111/j.1574-6976.1993.tb00018.x

Qin X, Singh KV, Weinstock G M, Murray BE (2000) Effects of Enterococcus faecalis fsr genes on production of gelatinase and a serine protease and virulence. Infect Immun 68: 2579-2586. https://doi. org/10.1128/IAI.68.5.25792586.2000

Quirós A, Ramos M, Muguerza B, Delgado MA, Miguel M, Aleixandre A, Recio I (2007) Identification of novel antihypertensive peptides in milk fermented with Entrococcus faecalis. Int Dairy J 17: 33-41. https://doi.org/10.1016/j.idairyj.2005.12.011

Reid JR, Coolbear T, Pillidge CJ, Pritchard GG (1994) Specificity of hydrolysis of bovine K-Casein by cell envelope-associated proteinases from Lactococcus lactis strains. Appl Environ Microb 60: 801-806

Requena T, Pelaez C, Fox PF (1993) Peptidase and proteinase activity of Lactococeus lactis, Lactobacillus casei and Lactobacillus plantarum. Z Lebensm Unters For 196: 351-355. https://doi.org/10.1007/BF01197934

Semedo T, Santos MA, Lopes MFS, Marques JJF, Crespo MTB, Tenreiro $\mathrm{R}$ (2003) Virulence factors in food, clinical and reference enterococci: a common trait in the genus? Syst Appl Microbiol 26: 13-22. https://doi.org/10.1078/072320203322337263

Shankar N, Lockatell CV, Baghdayan AS, Drachenberg C, Gilmore MS, Johnson DE (2001) Role of Enterococcus faecalis surface protein Esp in the pathogenesis of ascending urinary tract infection. Infect Immun 69: 4366-4372. https://doi.org/10.1128/IAI.69.7.4366-4372.2001

Solheim M, Aakra A, Snipen LG, Brede DA, Nes IF (2009) Comparative genomics of Enterococcus faecalis from healthy Norwegian infants. BMC Genomics 10: 1-11. https://doi.org/10.1186/1471-2164-10-194

Spellman D, McEvoy E, O'Cuinn G, FitzGerald RJ (2003) Proteinase and exopeptidase hydrolysis of whey protein: comparison of the TNBS, OPA and $\mathrm{pH}$ stat methods for quantification of degree of hydrolysis. Int Dairy J 13: 447-453. https://doi.org/10.1016/S09586946(03)00053-0

Thomas TD, Pritchard GG (1987) Proteolytic enzymes of dairy starter cultures. FEMS Microbiol Rev 46: 245-268. https://doi. org/10.1016/0378-1097(87)90111-X

Thurlow LR, Thomas VC, Narayanan S, Narayanan S, Olson S, Fleming SD, Hancock LE. (2010) Gelatinase contributes to the pathogenesis of endocarditis caused by Enterococcus faecalis. Infect Immun 78: 4936-4943. https://doi.org/10.1128/IAI.01118-09

Vankerckhoven V, Van Autgaerden T, Vael C, Lammens C, Chapelle S, Rossi R, Jabes D, Goossens H (2004) Development of a multiplex PCR for the detection of asa1, gelE, cylA, esp, and byl genes in enterococci and survey for virulence determinants among European hospital isolates of Enterococcus faecium. J Clin Microbiol 42: 44734479. https://doi.org/10.1128/JCM.42.10.4473-4479.2004

Wilkinson MG, Guinee TP, O'Callaghan DM, Fox PF (1994) Autolysis and proteolysis in different strains of starter bacteria during Cheddar cheese ripening. J Dairy Res 61: 249-262. https://doi. org/10.1017/S0022029900028260 